\title{
The Immune Microenvironment in Head and Neck Squamous Cell Carcinoma: on Subsets and Subsites
}

\author{
Niels E. Wondergem ${ }^{1} \cdot$ Irene H. Nauta ${ }^{1} \cdot$ Tara Muijlwijk $^{1} \cdot$ C. René Leemans ${ }^{1} \cdot$ Rieneke van de Ven $^{1}$ (D)
}

Published online: 29 June 2020

(C) The Author(s) 2020

\begin{abstract}
Purpose To understand why some patients respond to immunotherapy but many do not, a clear picture of the tumor microenvironment (TME) of head and neck squamous cell carcinoma (HNSCC) is key. Here we review the current understanding on the immune composition per HNSCC subsite, the importance of the tumor's etiology and the prognostic power of specific immune cells.

Recent Findings Large cohort data are mostly based on deconvolution of transcriptional databases. Studies focusing on infiltrate localization often entail small cohorts, a mixture of HNSCC subsites, or focus on a single immune marker rather than the interaction between cells within the TME.

Summary Conclusions on the prognostic impact of specific immune cells in HNSCC are hampered by the use of heterogeneous or small cohorts. To move forward, the field should focus on deciphering the immune composition per HNSCC subsite, in powered cohorts and considering the molecular diversity in this disease.
\end{abstract}

Keywords Head and neck squamous cell carcinoma · Tumor microenvironment · Innate and adaptive immune system · Tumor infiltrating lymphocytes · Prognosis $\cdot$ HNSCC subsites

\section{Introduction}

Head and neck squamous cell carcinoma (HNSCC) annually affects more than 700,000 patients globally, leading to over 350,000 deaths in 2018 [1]. It arises in the mucosal linings of the upper aerodigestive tract including the oral cavity, oropharynx, hypopharynx, and larynx. The most important risk factors for HNSCC are the use of tobacco, excessive alcohol consumption, and persistent infection with high-risk human papillomavirus (HPV) [2]. Despite aggressive and toxic treatment regimens including (a combination of) surgery, chemotherapy, and radiotherapy the 5-year overall survival (OS) remains a mere $40-50 \%$ and has seen little improvement in

Irene H. Nauta and Tara Muijlwijk contributed equally to this work.

This article is part of the Topical Collection on Head and Neck Cancers

Rieneke van de Ven

r.vandeven@amsterdamumc.nl

1 Department of Otolaryngology-Head and Neck Surgery, Cancer Center Amsterdam, Amsterdam UMC, VU University medical center, De Boelelaan, 1117 Amsterdam, The Netherlands the past decades [3]. The effect of the recent addition of immune checkpoint inhibitors to the clinicians' arsenal for recurrent and metastatic HNSCC on survival is therefore highly anticipated [4].

Treatment response and tumor progression are influenced by the interaction between the tumor and its surroundings, the tumor microenvironment (TME). Rather than considering the tumor as a group of malignant cells, the TME represents a complex eco-system in which the tumor and other constituents of the TME, such as T cells, B cells, natural killer (NK) cells, myeloid derived suppressor cells (MDSC), macrophages, dendritic cells (DC), and cancer associated fibroblasts (CAF), interact with each other. Tumor infiltrating lymphocytes (TILs) are considered the most crucial effectors of the host anti-tumor immune response, and their presence has been linked to improved survival in several cancer types accordingly $[5,6]$. However, tumors have developed several mechanisms to escape the host immune response, including downregulation of HLA class I expression to avoid T cell recognition [7], induction of $\mathrm{T}$ cell apoptosis [8], recruitment of immunosuppressive cells such as regulatory $\mathrm{T}$ cells (Tregs), MDSCs, or M2 macrophages [9], inactivation of the antigen processing machinery preventing processing and presentation 
of tumor-associated antigens [9], and upregulation of checkpoint inhibitory molecules [10]. Additionally, tumor cells are under selective pressure through a dynamic process known as immunoediting, in which less immunogenic tumor cells are positively selected for their ability to escape the immune system and thus gain a survival advantage [11].

In recent years, the tumor immune microenvironment has gained much interest, especially in light of the recent advances in immunotherapy. The notion that the vast majority of HNSCCs are not destroyed upon anti-PD-1 checkpoint inhibition suggests that other immune suppressive mechanisms might be at play. In this review, we outline the various players in the TME of HNSCC and evaluate their function and prognostic significance. In addition, we discuss the current data available linking molecular alterations in HNSCC to the immune composition within the TME. Since HNSCC can be divided into HPV-related (mainly oropharyngeal squamous cell carcinomas (OPSCCs)) and HPV-unrelated (i.e., smoking- and alcohol-related) disease, it can be expected that the TME of both disease entities may vary. HPV-related HNSCCs are appreciated as a separate type of cancers since they differ significantly with respect to genomic and molecular aspects, clinical outcome, and immune microenvironment $[12 \bullet, 13,14]$. In general, HPV-related HNSCC exhibit increased immune infiltrate compared with HPV-unrelated tumors $[15,16,17 \bullet, 18]$. Published studies where HPV status is not considered should therefore be interpreted with caution.

\section{Innate Immune Effector Cells}

Innate effector cells, such as NK cells and neutrophils are seen as the first responders in case of tissue damage. Their functionality in the context of cancer is more often studied in the peripheral blood rather than at the tumor site. Relevant existing data on neutrophil- and NK cell presence in the TME is outlined below.

\section{Neutrophils}

Neutrophils, or their precursors, can be attracted by developing tumor cells that secrete factors like IL-8, CCL4, or CCL5. Tumor-associated neutrophils (TAN) can be polarized towards an anti-tumor N1 phenotype and a pro-tumor N2 phenotype, dependent on the growth factors present within the TME [19]. N2-type TAN can promote tumor growth by supporting genetic instability, angiogenesis, cancer metastasis, and immune suppression [19, 20]. Regarding the presence of neutrophils in HNSCC, Trellakis et al. studied infiltration of polymorphonuclear granulocytes (PMNs) in tumors in the oropharynx $(n=71)$ and hypopharynx $(n=28)$ by staining for cells expressing the granulocytic marker CD66b or the azurophilic granule marker myeloperoxidase (MPO) [21]. The majority of the patients had stage IV disease (78\%). PMN infiltration was observed in $93 \%$ of the studied cases, either in the tumor or the stroma. T4 tumors were found to be more highly infiltrated by PMN than lower T stage tumors. In a selection of advanced disease patients $(n=$ 40) medium or strong PMN infiltration was a negative prognostic factor for OS in multivariate Cox regression analysis $(p=0.048)$. Dumitru et al. found a similar reduced survival in patients with oro- or hypopharyngeal cancer with high neutrophil infiltration and especially patients with multiple nodal metastasis had high rates of TAN [22]. The most unfavorable outcome was observed in this study when neutrophil infiltration was combined with expression of the actin-binding protein cortactin, suggestive of an interaction between TAN and cortactin in the TME promoting metastatic spread [22]. Reports on the quantification of neutrophils at other HNSCC subsites are lacking to date.

\section{NK Cells}

NK cells can have direct cytolytic effect by producing factors like perforins and granzymes and they can secrete interferon- $\gamma$ (IFN- $\gamma$ ), which promotes activation of myeloid cells and $\mathrm{T}$ helper-1 (Th1) cells. They can also promote tumor cell apoptosis via FasL or TNF-related apoptosis-inducing ligand (TRAIL). Additionally, NK cells can kill antibody-bound tumor cells through antibody-dependent cellular cytotoxicity (ADCC). Considering the latter, it is quite surprising that little is known on the presence of NK cells within the TME, since the immunological working-mechanism of the epidermal growth factor receptor (EGFR)-targeted antibody Cetuximab, used in the treatment of HNSCC, relies on NKcell mediated ADCC [23]. In The Cancer Genome Atlas (TCGA) analyses ( $n=500$ HNSCC cases), HNSCC ranked third highest for the expression of NCR1 mRNA, which encodes the NK-specific marker NKp64 [24]. Patients with high NCR1 expression had a significantly better OS $(p=0.016)$. Looking at presented flow data for tumor-infiltrating leukocytes (TIL) in two HNSCC patients (from a cohort of $n=6$ ), NK cells seem only a minor cell fraction within the viable TIL gate in these patients $(0.45 \%$ or $0.98 \%$ of viable TIL, compared to $65 \%$ and $54 \% \mathrm{CD}^{+} \mathrm{T}$-cells, respectively). Wagner et al. quantified $\mathrm{CD}^{+} 6^{+} \mathrm{NK}$ cells in OPSCC $(n=140: 34$ HPV-related, $106 \mathrm{HPV}$-unrelated) and found significantly higher NK cell density in HPV-related tumors and adjacent stroma compared to HPV-unrelated tumors $(p=0.004)$ [25]. NK cells were more abundant in the stroma compared to the tumor area. Co-staining with granzyme B and CD16 suggested the infiltrating NK cells to mainly represent cytotoxic NK cells, although potentially regulatory NK cells, lacking these markers, were detected and this was seen more often in HPV-unrelated tumors than in HPV-related tumors. In univariate Kaplan-Meier analyses, presence of $\mathrm{CD}^{2} 6^{+} \mathrm{NK}$ cells in either the tumor and/ or stroma was linked to a better survival, both in HPV-related 
and HPV-unrelated disease. Mandal et al. also reported improved survival of HNSCC patients with high NK cell infiltration based on TCGA data [16].

\section{Myeloid Cells}

\section{Dendritic Cells}

DCs are antigen-presenting cells (APCs) which link the innate with the adaptive immune system. They pick up antigens at the site of the tumor and, when properly activated, are able to induce a tumor-specific $T$ cell response. Early studies already suggest that a greater number of myeloid DCs (mDCs) is associated with increased TILs, lower rate of metastases, less recurrence, and improved survival in patients with HNSCC $[26,27]$. Recent studies confirm this positive correlation [28-32]. This implies that DCs play a pivotal role in the immunosurveillance of the host against HNSCC. Contrary, several studies did not replicate the link between DC density and clinical parameters [33-37]. Collectively, there is no consistency concerning the prognostic significance of DC density for HNSCC. This may be explained by small study sizes, discrepancy concerning the type of DC markers, and heterogeneous patient populations. By way of illustration, tumor subsite, which has significant impact on the immune landscape $[12 \bullet, 13,14]$, varied within and between aforementioned studies. Moreover, HPV status was not always included. HPV E6 and E7 may impede with macrophage inflammatory protein 3 (MIP-3) transcription and E-cadherin levels leading to reduced DC activity [38, 39]. In studies where HPV status was included, some found elevated DC numbers in HPV-related HNSCC $[12 \bullet, 15]$, while others observed no differences $[17 \bullet, 40]$. Notably, Kindt et al. detected significantly lower DCs in HPV-related compared with HPVunrelated tumors [14]. The prognostic value of DCs when including HPV status is still poorly studied. Nguyen et al. could not find a significant correlation between DC levels and survival after controlling for among others HPV status [12 •]. In addition, Kindt et al. observed no correlation between the number of DCs and survival of HPV-related HNSCCs. However, the DC number was significantly associated with increased recurrence free survival and OS in HPV-unrelated disease [14]. Taken together, the prognostic relevance of mDCs in HNSCC remains unresolved.

Besides mDCs, plasmacytoid DCs (pDCs) infiltrate the TME of HNSCC [34, 41-43]. At steady state, pDCs circulate in the blood and can be found in lymphoid organs. Upon infection, pDCs infiltrate peripheral tissues [44]. Within the TME, pDCs predominately reside within the connective tissue, close to the tumor [34, 41-43]. pDCs are able to elicit an anti-tumor response by secreting high levels interferon- $\alpha$ (IFN- $\alpha$ ) upon triggering of the Toll-like receptor 9 (TLR9)
[44]. However, it appears that pDCs display diminished IFN- $\alpha$ production in HNSCC $[41,42]$. Also, tumors are able to downregulate TLR-9 on pDCs [41], indicating that although pDCs infiltrate the TME, their ability to elicit an anti-tumor response is diminished. Moreover, it has been suggested that pDCs in the absence of appropriate stimulation promote tolerance by inducing Tregs $[41,45]$. In concordance with this, enhanced pDC numbers significantly associate with tumor size, lymph node metastases, and poor clinical outcome in HNSCC $[34,42]$. Han et al. demonstrated that infiltrating pDCs are an independent prognostic factor. They also examined whether the number of pDCs differed upon HPV-status but found no correlation between pDCs and HPV infection [42]. Contrary, Partlová et al. observed more pDCs in HPVrelated HNSCC, but this difference was not significant [15]. Additional studies are required to understand the prognostic value of pDCs at different HNSCC subsites and in relation to HPV-status.

\section{Macrophages}

Macrophages are found in abundance within the TME and appear in different phenotypes. Macrophages activated by IFN- $\gamma$ polarize into a M1 phenotype and contribute to antitumor immune responses, as opposed to M2 macrophages, driven by interleukin (IL)-4, which are characterized by stimulating anti-inflammatory and pro-tumoral responses [46-48]. It has become evident that the density of $\mathrm{CD}^{+} 8^{+}$cells, a general marker for macrophages, is elevated in HNSCC compared

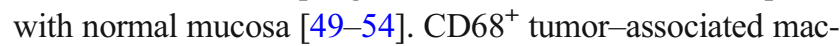
rophages (TAMs), defined as macrophages located in or close by the tumor, were found to correlate with lymph node metastases and poor survival in HNSCC [49-52, 54-58]. This correlation was not observed in all studies [12•, 59-62]. Of note, the expression of CD163, a specific M2 marker [63], may be prognostically more informative. HNSCC cells drive TAMs towards M2 polarization [64]. In turn, M2 TAMs contribute to migration and invasion of HNSCC cells $[65,66]$. Accordingly, two studies found no association between CD68 positivity and clinical outcome while increased CD163 TAMs were an independent prognostic factor [61, 62]. The prognostic value of $\mathrm{M} 2$ TAMs was confirmed by several other studies [58, 67-69], though not in all [32, 70].

The ratio of M1/M2 TAMs indicates a better prognosis in both HPV-related and HPV-unrelated HNSCC, and it has been reported that HPV-related tumors have a higher M1/ M2 ratio [17•]. Furthermore, lower M2/CD68 ${ }^{+}$TAM ratios have been observed in HPV-related HNSCC compared with HPV-unrelated [12•, 52, 60, 71, 72]. In line with this, HPVunrelated tumors display augmented M2 infiltration [73]. While aforementioned studies show consistency, several studies could not replicate these differences in CD68 and/or CD163 expression between HPV-unrelated and HPV-related 
tumors $[53,59,69,70,74]$. These discrepant results may be explained by variation in tumor subsites, treatment, or cutoff values concerning marker expression. In summary, compelling evidence suggests a role for M2 TAMs in the progression of HNSCC. HPV-related tumors seem to be more enriched for M1 TAMs, while HPV-unrelated tumors appear to be more enriched for M2 TAMs.

\section{Myeloid-Derived Suppressor Cells}

MDSCs are characterized by their ability to inhibit the innate as well as adaptive immune system. They suppress $\mathrm{CD} 4^{+}$and $\mathrm{CD} 8^{+} \mathrm{T}$ cells, induce Tregs, and act together with macrophages resulting in a shift towards an immunosuppressive phenotype by elevating levels of IL-10 and decreasing IL-12 [75-77]. Elevated levels of MDSCs in HNSCC compared to normal mucosa have been described [53, 74, 78, 79]. Moreover, increased accumulation of MDSCs correlates with high clinical stage and pathological grade [79]. It remains elusive whether the infiltration of MDSCs differs upon HPV status. Although three studies concluded that MDSC levels do not differ between HPV-related and HPV-unrelated HNSCC $[53,69,74]$, additional studies are required to confirm this.

\section{Adaptive Immune Cells}

\section{CD8 $^{+}$Effector T Cells}

After activation by antigenic and cytokine stimulation by APCs like DCs, naïve $\mathrm{CD} 8^{+} \mathrm{T}$ cells differentiate into either memory or cytotoxic effector $\mathrm{T}$ cells [80]. Cytotoxic $\mathrm{T}$ cells constitute a subset of $\mathrm{T}$ cells with the ability to recognize and kill tumor cells and therefore serve as central players within the anti-tumor response. Indeed many studies report a positive correlation of higher $\mathrm{CD} 8^{+}$TIL with improved survival in HNSCC patients [32, 81-85]. However, the effect seems to be affected by tumor subsite, relative amount to other tumor infiltrating immune cells, spatial distribution, and HPV status.

In OCSCC, a prognostic benefit of high $\mathrm{CD}^{+}$TIL has been described [85-89, 90*], but the majority of reports show no significant association of high $\mathrm{CD} 8^{+} \mathrm{TIL}$ with OS or DSS $[56,91-96]$. This lack of consistency might in part be explained by the relative amounts of $\mathrm{CD} 8^{+}$TILs to other TILs affecting their function. For instance, a high $\mathrm{CD} 8^{+} / \mathrm{CD}^{+}$ratio confers superior DSS and DFS [97], and a low $\mathrm{CD} 8^{+} /$forkhead box protein 3 (FoxP3) ratio confers inferior OS and DFS [98, 99]. Interestingly, two recent meta-analyses on the role of $\mathrm{CD}^{+} \mathrm{T}$ cells in OCSCC showed contradictory results. This could be due to the low amount of studies that qualified for meta-analysis, especially by Hadler-Olsen et al. [100, 101].

In OPSCC, the prognostic role of $\mathrm{CD} 8^{+}$TILs seems more pronounced with a substantial amount of papers reporting a positive effect on survival of high $\mathrm{CD} 8^{+} \mathrm{TIL}$ both stromal and intratumoral [59, 85, 102-108]. HPV-related OPSCC show a significantly higher infiltration of $\mathrm{CD}^{+} \mathrm{T}$ cells $[12 \bullet, 15,70$, $74,82,85,104-106]$. In fact, it has been reported that HPVrelated OPSCC patients with a low $\mathrm{CD} 8^{+} \mathrm{TIL}$ count do not show the typical improved survival associated with HPVrelated OPSCC [109]. This could point to a role for the local immune response in the survival of HPV-related OPSCC patients. Not all studies were able to find this association, however [110]. Although investigated to a lesser extent, high $\mathrm{CD}^{+}$TIL counts have been associated with survival benefit in laryngeal squamous cell carcinoma [85, 111, 112].

\section{CD4 $^{+} \mathrm{T}$ Cells}

$\mathrm{CD} 4^{+} \mathrm{T}$ cells represent a heterogeneous cell type which can be sub-classified into various subtypes including Th1, Th2, Th9, Th17, follicular helper $\mathrm{T}$ cells (Tfh), and Tregs [113]. This hampers the evaluation of their role in HNSCC as observed effects could be attributable to any of these subtypes, and staining for CD4 alone might not be sufficient. This could explain the ambiguous role of $\mathrm{CD}^{+}{ }^{+} \mathrm{T}$ cells in HNSCC: some papers report a favorable prognostic effect of higher $\mathrm{CD} 4^{+}$ TIL $[12 \bullet, 85,114]$, while others report the opposite [88, 115]. However, no significant association between $\mathrm{CD} 4^{+}$ TIL and survival has been reported most frequently $[81,86$, 91, 94, 96, 102]. Although in their meta-analyses, de Ruiter et al. did find a prognostic benefit of higher $\mathrm{CD}^{+} \mathrm{T}$ cell infiltration in HNSCC, the authors stress to interpret this with caution given the paucity of papers eligible for analyses and a high suspicion of publication bias [84]. In two recent metaanalyses for OCSCC specifically, Huang et al. report no prognostic value [100], whereas Hadler-Olsen et al. found data to be insufficient for analyses [101]. Recently, Cillo et al. [116•] reported on scRNAseq comparing HPV-related and HPVunrelated HNSCC, and showed that HPV-related tumors are enriched in the presence of a Tfh cell population when compared with HPV-unrelated tumors. In TCGA data, a Tfh-high profile corresponded with improved survival [116•]. It must be mentioned that while the majority of HPV-related tumors in this study were OPSCC, the HPV-unrelated tumors were a mix of OCSCC, OPSCC, larynx, and hypopharynx. In all, the role of $\mathrm{CD}^{+} \mathrm{T}$ cells in HNSCC remains to be clarified. Investigation of $\mathrm{CD}^{+} \mathrm{T}$ cell subpopulations at various HNSCC subsites specifically is warranted.

\section{Regulatory T Cells}

Tregs are a subpopulation of $\mathrm{CD} 4^{+} \mathrm{T}$ cells which can be identified by the expression of the transcription factor FoxP3 [113]. They play a critical role in maintaining host-tolerance and thus preventing auto-immunity, by regulating other immune cells including DCs, NK cells, B-cells, $\mathrm{CD}^{+}{ }^{+}$and $\mathrm{CD} 8^{+}$ 
$\mathrm{T}$ cells, but in doing so also facilitate tumor immune escape and tumor progression [117]. Indeed a large meta-analysis on the prognostic value of FoxP3 showed that high Treg infiltration is associated with inferior OS in several tumor types, but not in HNSCC [118]. In fact, when considering HNSCC in general, higher $\mathrm{CD} 4^{+} \mathrm{FoxP} 3^{+} \mathrm{T}$ cell infiltration correlates with better survival $[30,119,120]$. This does however not seem to apply to all HNSCC subsites as for OCSCC most studies do report lower $\mathrm{CD}^{+}{ }^{+} \mathrm{FoxP}^{+}{ }^{+} \mathrm{TIL}$ counts to be related with improved survival [121-124]. Only one study found an association in the opposite direction [97], but most, including two meta-analyses, failed to show a significant correlation of FoxP3 with survival in OCSCC [89, 92, 100, 101, 125].

Echarti et al. recently reported high stromal numbers of Tregs to be correlated with improved survival in HNSCC, and epithelial numbers of Tregs to only gain prognostic importance when stratifying for "inflamed", "immune excluded", and "immune desert" tumors based on total number of infiltrating $\mathrm{CD}^{+} \mathrm{T}$ cells [126]. This might in fact represent the $\mathrm{CD}^{+} / \mathrm{FoxP}^{+}$ratio, which confers survival benefit when lower in OCSCC, as published previously by Chen et al. and more recently by $\mathrm{Ni}$ et al. [99, 124]. Interestingly, the intracellular localization of FoxP3 might play a role, as a shift in the subcellular localization of FoxP3 expression from cytoplasmic to nuclear has been described after TCR/CD28 activation [127, 128]. This indicates that a subgroup of $\mathrm{FoxP}^{+} \mathrm{T}$ cells might in fact have an effector function. Weed et al. have found that in OCSCC, cytoplasmic localization of FoxP3 was associated with lower risk of recurrence, as opposed to nuclear localization [129]. In addition, Feng et al. report the spatial relation of FoxP3 $^{+} \mathrm{T}$ cells to $\mathrm{CD} 8^{+} \mathrm{T}$ cells to affect OS in OCSCC. In their study using multispectral imaging on $119 \mathrm{HPV}$-unrelated OCSCC, they showed that a higher density of $\mathrm{FoxP}^{+} \mathrm{T}$ cells within $30 \mu \mathrm{m}$ of $\mathrm{CD}^{+} \mathrm{T}$ cells was significantly associated with worse OS [90•].

In OPSCC, a positive correlation of higher $\mathrm{CD}^{+} \mathrm{FoxP}^{+} \mathrm{T}$ cell infiltration with improved survival is reported $[59,85,120$, $130,131]$, but a significant association with poor survival has also been described [132]. When considering HPV, it seems that papers reporting significantly higher $\mathrm{CD} 4{ }^{+} \mathrm{FoxP} 3^{+}$infiltration in HPV-related OPSCC [103, 130, 131, 133] are in balance with reports that do not find such relation [104, 106, 120, 134, 135]. In their study, Ward et al. reported higher absolute counts of FoxP $3^{+} \mathrm{T}$ cells in HPV-related OPSCC and correlated this to improved survival [109]. However, the authors state the observed absolute increase could merely be a reflection of higher overall $\mathrm{T}$ cell infiltration in HPV-related OPSCC, since relative amounts of FoxP3 did not differ significantly. One other study described such correlation [131]. In their meta-analysis, de Ruiter et al. were unable to analyze HPV-related tumors due to insufficient data [84].

\section{B Lymphocytes}

The composition and prognostic role of B-cells in the TME of HNSCC is relatively understudied. As part of the adaptive immune system, B lymphocytes play an important role in the immune response following the onset of malignant tumors [136]. Mature B cells can produce antibodies which could bind to tumor cells and induce ADCC by NK cells or Fcreceptor mediated phagocytosis by macrophages, they can also act as APCs or can directly interact with $\mathrm{CD}^{+} \mathrm{T}$ cells (through $\mathrm{CD} 40 / \mathrm{CD} 40 \mathrm{~L}$ ) or $\mathrm{CD} 8^{+} \mathrm{T}$ cells (through CD27/CD70), thereby, providing help to the anti-tumor immune response [137]. In addition to these anti-tumor features, regulatory B-cells (Bregs) are thought to stimulate tumor growth by negatively interacting with other immune cells as well as with tumor cells. It is assumed that Bregs inhibit NK cell- and cytotoxic $\mathrm{T}$ cell-mediated tumor immunity, suppress the differentiation of Th1/Th17 cells, and promote the alteration of T-helper cells and macrophages towards the Th2/M2 types. Moreover, Bregs might disable the cellular immune response against the tumor by promoting the conversion of $\mathrm{CD}^{+} / \mathrm{CD} 25^{-} \mathrm{T}$ lymphocytes to FoxP3 ${ }^{+}$Tregs, thereby, enabling tumor growth and the development of metastasis. Bregs secrete IL-6, IL-10, IL-35, and TGF- $\beta$, all known for their suppressive effect on the immune response [138].

HPV-related HNSCC were shown to contain increased percentages of tumor-infiltrating $\mathrm{CD} 19^{+} / \mathrm{CD} 20^{+} \mathrm{B}$ lymphocytes compared with HPV-unrelated HNSCC and non-cancerous mucosa $[17 \bullet, 70,74,139 \bullet, 140,141]$. When performing RNA-sequencing, it was even shown that phenotypic differences exist between B lymphocytes in HPV-related and HPVunrelated HNSCC [140]. Hladíková et al. found that in HPVrelated OPSCCs, the B cell population within the TME seems to be represented mainly by memory B lymphocytes with an activated, antigen-experienced phenotype, characterized by high expression of CD27, no expression of IgD and low expression of IgM [141]. When they subsequently divided the HPV-related OPSCCs into two groups based on the amount of $\mathrm{B}$ cell infiltrate ( $\mathrm{B}^{\text {low }}$ (B cell proportions $<0.5 \%$ of total cells) versus $\mathrm{B}^{\mathrm{hi}}$ tumors), they noticed that in the $\mathrm{B}^{\text {hi }}$ group the tumor-infiltrating $\mathrm{B}$ cells displayed significantly higher levels of activation markers like HLA-ABC, HLA-DR, CD86, and $\mathrm{CD} 40$ when compared with the $\mathrm{B}^{\text {lo }}$ group, corresponding with an activated phenotype. Moreover, $\mathrm{B}^{\text {hi }}$ OPSCCs possessed higher proportions of proliferating $\mathrm{Ki}-67^{+} \mathrm{B}$ cells than the $\mathrm{B}^{\text {low }}$ counterparts [141].

The prognostic impact of B lymphocytes in the TME of HNSCC remains somewhat ambiguous. While most studies report a favorable effect of B lymphocytes on HNSCC patient survival [17, 141-143], some studies fail to find any effect on survival [70] or even claim that certain subsets of B cells, particularly Bregs, may contribute to an immunosuppressive, cancer promoting microenvironment [144]. Distel et al. 
demonstrated that the prognostic impact of $\mathrm{CD} 20^{+} \mathrm{B}$ cells may be dependent on the type of treatment and stage of disease [145]. In their study, they investigated 115 patients with oro- or hypopharyngeal squamous cell carcinoma by dividing them in two groups: a low-risk group $(n=62)$ of early stage disease treated with primary surgery and postoperative radiotherapy, and a high-risk group $(n=53)$ of inoperable, advanced stage disease treated with definitive chemoradiotherapy. Immunohistochemistry for CD3, CD4, CD8, CD20, $\mathrm{CD} 68$, FoxP3, and granzyme $\mathrm{B}$ was performed on all pretreatment biopsies and percentages of the various subsets of TIL were correlated with survival. Surprisingly, it was observed that in the low-risk group higher numbers of $\mathrm{CD} 20^{+} \mathrm{B}$ cells were consistently associated with improved locoregional tumor control $(p=0.02)$, while it was negatively associated with prognosis in the high-risk group $(p=0.04)$. Of note, B cells have the ability to form tertiary lymphoid structures (TLS) when they aggregate in a network of follicular DCs surrounded by $\mathrm{T}$ cells and high-endothelial venules [146]. In OCSCC, TLS are more frequently seen in stage I-II than in stage III-IV disease, and the presence of TLS is associated with improved survival [147]. In their scRNAseq study, Cillo et al. reported an increased presence of germinal center $\mathrm{B}$ cells in HPV-related versus HPV-unrelated HNSCC, corresponding with the presence of TLS [116•].

\section{Stroma}

\section{Cancer-Associated Fibroblasts}

The most abundant, non-immune, cell type recognized in stroma are cancer-associated fibroblasts (CAFs). Without any doubt, CAFs promote tumor development by supporting tumor cell proliferation, invasion, and metastasis. The presence of CAFs within the TME often is linked with stromal desmoplasia through deposition of collagen. The most commonly used markers to identify CAFs are $\alpha$-smooth muscle actin ( $\alpha$-SMA), integrin $\alpha 6$, and fibroblast activation protein (FAP). In addition to producing growth factors like epidermal growth factor and vascular endothelial growth factor, CAFs produce matrix metalloproteinases that aid in the remodeling of the extracellular matrix and facilitate tumor outgrowth and metastasis. While much is known about the detrimental factors that are produced by CAFs, the exact origin of the CAFs within the TME remains quite elusive, as they have been described to derive from various different cell types [148]. CAFs promote immune suppression in the stromal compartment by producing high levels of TGF- $\beta$, IL-10, and IL- 6 , while at the same time recruiting many inflammatory cells through secreted chemokines [149].

In OCSCC in the tongue, the presence of CAFs, as identified by IHC, was found to be an independent prognostic factor, negatively impacting OS and DFS [150]. Similarly, CAF-related gene expression was linked to worse prognosis in OCSSC [151].

Multiple studies have looked at the effects of isolated CAFs and the factors they produce on the growth and invasion capacities of HNSCC cell lines [152,153]. While there is a general consensus that $\mathrm{CAFs}$ are a negative prognostic factor in HNSCC, surprisingly few studies can be found that actually tested this in (large) cohorts of patients by quantifying CAFs in the TME. The studies that are available primarily focus on the prognostic value of CAFs in OCSCC. Dhanda et al. stained 104 OCSCC for the CAF markers $\alpha$ SMA and SERPINE1 and found high expression to relate with poor clinical outcome and extracapsular spread [154]. In OPSCC $(n=44)$, the collagen proteins COL8A1 and COL11A1 were described to be expressed on tumor cells as well as CAFs in the TME. While a reduction in survival was mentioned, which did not reach statistical significance in this small group of patients, these data were not shown [155]. Puram et al. [156 $]$ performed single-cell RNAseq on $\sim 6000$ cells isolated from OCSCC samples $(n=18)$ and found CAFs to be a large determinant of the mesenchymal molecular subgroup of HNSCC previously identified by the TCGA workgroup [157]. This molecular subgroup is known for its invasive character and poor survival outcome and is dominated by genes related to epithelial to mesenchymal transition (EMT). Puram et al. propose that the tumor cells in this subgroup are similar to those defined in the basal molecular subgroup, but that the presence of CAFs within the TME promotes the EMT profile. There seems to be a void to be filled, where CAFs are quantified in the different subsites of HNSCC combined with immune composition analysis, not at the transcriptional level, but studying the actual cell numbers and their spatial localization.

\section{Molecular Landscape and TME}

The tumor mutational landscape and the TME are two of the major determinants of personalized medicine. To comprehensively characterize the TME, the effect of the mutational landscape on the TME should therefore be taken into consideration. We outline the few studies that have investigated their relation below.

Saloura et al. [73] studied the relation of genetic alterations to $\mathrm{CD} 8^{+} \mathrm{T}$ cell infiltration using both the TCGA and Chicago Head and Neck Genomics (CHGC) cohorts. Tumors were classified into high or low $\mathrm{CD} 8^{+} \mathrm{T}$ cell inflamed phenotype (TCIP-H vs TCIP-L) based on their chemokine signature. Results showed that TCIP-H tumors were enriched for mutations in CASP8, EP300, EPHA2, and HRAS and had more frequent amplifications of CD274, PDCD1LG2, JAK2, and KDM4C. TCIP-L tumors showed higher rates of NSD1 mutations, EGFR and YAP1 amplifications and CDKN2A 
Table 1 Overview of the current understanding of the prognostic value of different immune subsets at different HNSCC subsites. Green indicates $>50 \%$ of papers report positive correlation, red indicates $>50 \%$ of papers report negative correlation and yellow indicates $>50 \%$ of papers report no correlation, or number of studies reporting opposite effects are equal.
Size represents amount of papers considered. Small 0-5 papers; medium 6-10 papers; large $>10$ papers. Abbreviations: $H P V$, human papillomavirus; $N K$ cells, natural killer cells; $m D C$, myeloid dendritic cells; $p D C$, plasmacytoid dendritic cells; $M D S C$, myeloid derived suppressor cells; Tregs, regulatory T-cells; Bregs, regulatory B-cells

\begin{tabular}{|c|c|c|c|c|c|c|}
\hline & Oral cavity & $\begin{array}{l}\text { Oropharynx } \\
\text { (HPV-) }\end{array}$ & $\begin{array}{c}\text { Oropharynx } \\
(\mathrm{HPV}+)\end{array}$ & $\begin{array}{c}\text { Oropharynx } \\
\text { (HPV unspecified) }\end{array}$ & Larynx & Hypopharynx \\
\hline Neutrophils & & 0 & 0 & 0 & 0 & - \\
\hline NK cells & 0 & 0 & ○ & 0 & 0 & - \\
\hline $\mathrm{mDC}$ & & ○ & ○ & O & 0 & ○ \\
\hline $\mathrm{pDC}$ & 0 & 0 & 0 & O & 0 & 0 \\
\hline $\begin{array}{l}\text { Macrophages } \\
(\text { CD68 })^{+}\end{array}$ & & 0 & 0 & 0 & 0 & 0 \\
\hline M1/M2 ratio & 0 & O & ○ & 0 & 0 & 0 \\
\hline M2 (CD163 $\left.{ }^{+}\right)$ & & 0 & 0 & 0 & 0 & ○ \\
\hline MDSC & ○ & 0 & O & ○ & $\bigcirc$ & 0 \\
\hline $\mathrm{CD}^{+}{ }^{+}$T-cells & & ○ & 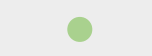 & 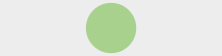 & 0 & - \\
\hline $\mathrm{CD}^{+}{ }^{+} \mathrm{T}$-cells & & ○ & 0 & O & ○ & 0 \\
\hline CD8/CD4 ratio & 0 & 0 & 0 & 0 & 0 & O \\
\hline CD8/FoxP3 ratio & ○ & 0 & O & 0 & 0 & O \\
\hline Tregs & & ○ & 3 & & 0 & 0 \\
\hline B-cells & 0 & ○ & 0 & 0 & 0 & ○ \\
\hline Bregs & 0 & 0 & 0 & (1) & O & 0 \\
\hline
\end{tabular}

deletion. Unfortunately, HPV-related tumors were too infrequent in the TCGA database to analyze the impact of HPV on the genetic landscape of TCIP-H and TCIP-L tumors. Mandal et al., also exploiting the TCGA database, showed that the proportion of mutational processes attributable to tobacco smoking inversely correlated with measures of immune 


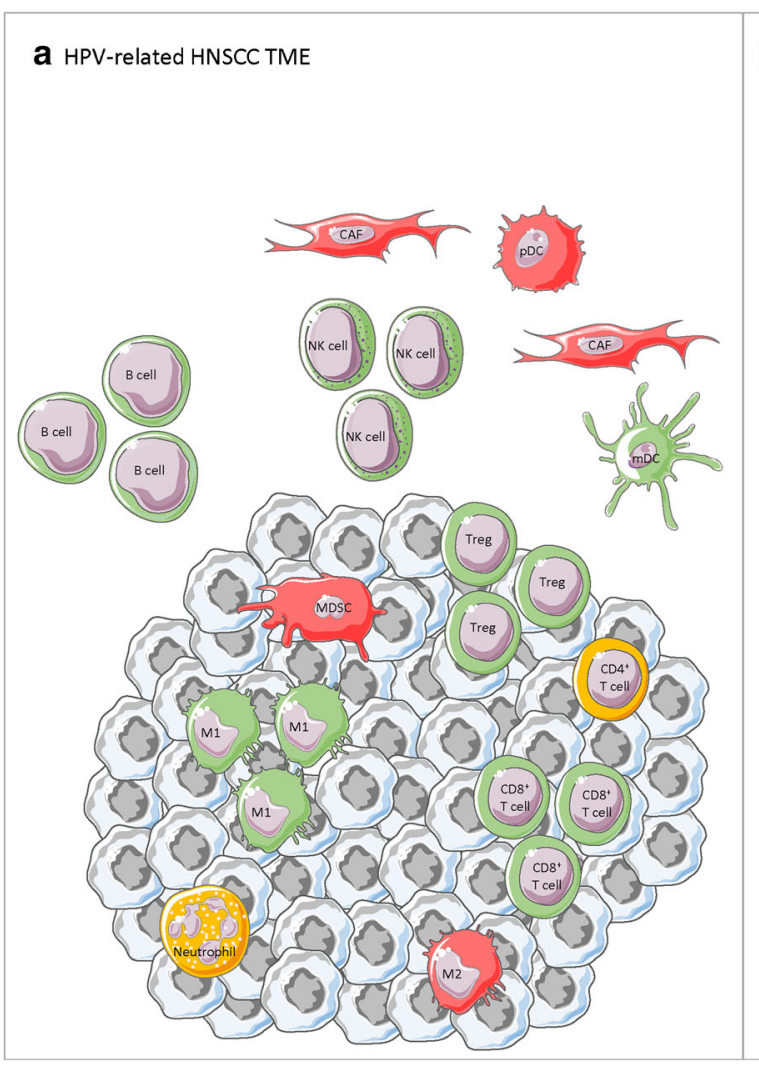

Fig. 1 Schematic overview of the current understanding on the differences between the immune cells infiltrating HPV-related (a) and HPV-unrelated (b) HNSCC. Abbreviations: CAF: cancer associated

infiltration, indicative of the immunosuppressive effect of tobacco smoking [16]. Although immunologically cold, these tumors were associated with high mutational loads. These tumors are expected to be more immunogenic due to higher neoantigen load [158], but in their study, Mandal et al. were unable to find any significant correlation of mutational load to measures of immune infiltration [16]. This was substantiated by Saloura et al. in their later study [73].

In a transcriptional study, linking TP53 mutational status in HNSCC with immune signatures, neutrophil, a NK cell, pDC, Treg, CD8+ TIL, and B cell gene signatures were reported to be significantly lower in TP53 mutated compared with TP53 wild-type tumors $(P=0.001)$ and higher in HRAS-mutated tumors $(p=0.033)$. [159]. For TP53 mutants, these subsets were lower both in HPV-related and HPV-unrelated tumors, though the significance was most pronounced between mutant and wild-type in HPV-related cases. Significantly fewer NK cells were reported to be present in TP53 mutant tumors compared with TP53 wild-type tumors $\left(p=6.4 \cdot 10^{-8}\right)$, and more NK cells were present in HRAS-mutated tumors than HRAS wild-type tumors $(p=0.012)$. Aligned with the data from Wagner et al. [25] NK cell-related genes were more abundant in HPV-related tumors than HPV-unrelated tumors [159].

All above analyses were performed on several multi-omics datasets, and HNSCC subsites were not specified.

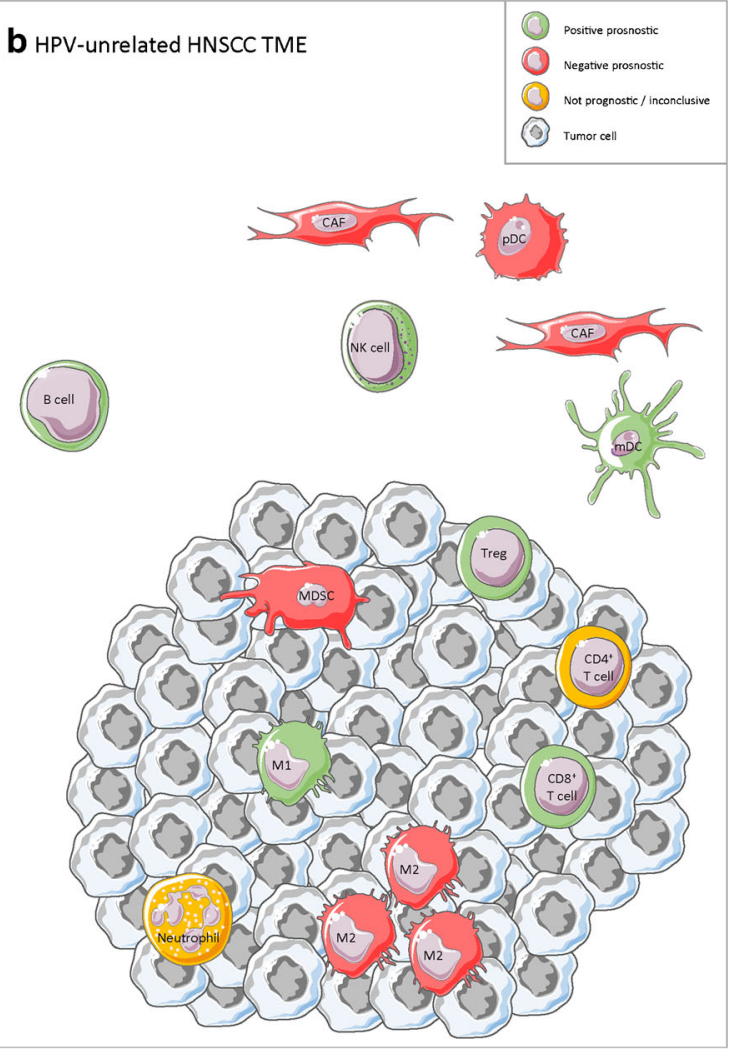

fibroblast; pDC: plasmacytoid dendritic cell; $\mathrm{mDC}$ : myeloid dendritic cell; NK cell: natural killer cell; M1: M1 macrophage; M2: M2 macrophage

\section{Conclusion and Future Directions}

In Table 1, we have combined the observations from the studies discussed in this review to provide an overview of the current understanding of the prognostic value of different immune subsets at different HNSCC subsites. While it seems evident that immune cells infiltrating the TME in HNSCC have relevance with regard to the clinical prognosis of patients, there is a clear need for more extensive studies to fill in some gaps. Our opinion is that the field should focus more on subsite specific analyses, clearly separating HPV-related and HPV-unrelated HNSCC. The current understanding on the differences between the immune cells infiltrating HPV-related and HPV-unrelated HNSCC and their link to prognosis are visualized in Fig. 1. Also, rather than focusing on studies trying to mine the presence of immune cells from large omics datasets, understanding the spatial interaction between tumor cells, immune cells, and CAFs in the stromal compartment, is in our opinion crucial to getting a better understanding of the TME in HNSCC. This will hopefully result in clearer answers on the prognostic power of the immune infiltrate, as a whole or of specific cell subsets, and will aid in defining those patients most likely to respond to (immuno)therapy strategies as well as create new hypotheses as to how to improve the immune infiltrate in patients who seem to fit a less favorable profile. 


\section{Compliance with Ethical Standards}

Conflict of Interest Niels Wondergem has conducted clinical trials with Bristol-Myers Squibb.

Irene Nauta declares that she has no conflict of interest.

Tara Muijlwijk declares that she has no conflict of interest.

Rieneke van de Ven declares she receives research funding from Genmab BV.

René Leemans has conducted clinical trials with Bristol-Myers Squibb and is on the global advisory board of Merck \& Co., Inc. and Rakuten Medical advisory board.

Human and Animal Rights This article does not contain any studies with human or animal subjects performed by any of the authors.

Open Access This article is licensed under a Creative Commons Attribution 4.0 International License, which permits use, sharing, adaptation, distribution and reproduction in any medium or format, as long as you give appropriate credit to the original author(s) and the source, provide a link to the Creative Commons licence, and indicate if changes were made. The images or other third party material in this article are included in the article's Creative Commons licence, unless indicated otherwise in a credit line to the material. If material is not included in the article's Creative Commons licence and your intended use is not permitted by statutory regulation or exceeds the permitted use, you will need to obtain permission directly from the copyright holder. To view a copy of this licence, visit http://creativecommons.org/licenses/by/4.0/.

\section{References}

Papers of particular interest, published recently, have been highlighted as:

- Of importance

1. Bray F, Ferlay J, Soerjomataram I, Siegel RL, Torre LA, Jemal A. Global cancer statistics 2018: GLOBOCAN estimates of incidence and mortality worldwide for 36 cancers in 185 countries. CA Cancer J Clin. 2018;68(6):394-424. https://doi.org/10.3322/ caac. 21492

2. Leemans CR, Snijders PJF, Brakenhoff RH. The molecular landscape of head and neck cancer. Nat Rev Cancer. 2018;18(5):26982. https://doi.org/10.1038/nrc.2018.11.

3. Marur S, Forastiere AA. Head and neck cancer: changing epidemiology, diagnosis, and treatment. Mayo Clin Proc. 2008;83(4): 489-501. https://doi.org/10.4065/83.4.489.

4. Moskovitz J, Moy J, Ferris RL. Immunotherapy for head and neck squamous cell carcinoma. Curr Oncol Rep. 2018;20(2):22. https:// doi.org/10.1007/s11912-018-0654-5.

5. Kotoula V, Chatzopoulos K, Lakis S, Alexopoulou Z, Timotheadou E, Zagouri F, et al. Tumors with high-density tumor infiltrating lymphocytes constitute a favorable entity in breast cancer: a pooled analysis of four prospective adjuvant trials. Oncotarget. 2016;7(4):5074-87. https://doi.org/10.18632/ oncotarget.6231.

6. Geng Y, Shao Y, He W, Hu W, Xu Y, Chen J, et al. Prognostic role of tumor-infiltrating lymphocytes in lung cancer: a meta-analysis. Cell Physiol Biochem. 2015;37(4):1560-71. https://doi.org/ $10.1159 / 000438523$.

7. Ferris RL, Hunt JL, Ferrone S. Human leukocyte antigen (HLA) class I defects in head and neck cancer: molecular mechanisms and clinical significance. Immunol Res. 2005;33(2):113-33. https://doi.org/10.1385/IR:33:2:113.

8. Whiteside TL. Tumor-induced death of immune cells: its mechanisms and consequences. Semin Cancer Biol. 2002;12(1):43-50. https://doi.org/10.1006/scbi.2001.0402.

9. Ferris RL, Whiteside TL, Ferrone S. Immune escape associated with functional defects in antigen-processing machinery in head and neck cancer. Clin Cancer Res. 2006;12(13):3890-5. https:// doi.org/10.1158/1078-0432.CCR-05-2750.

10. Zandberg DP, Strome SE. The role of the PD-L1:PD-1 pathway in squamous cell carcinoma of the head and neck. Oral Oncol. 2014;50(7):627-32. https://doi.org/10.1016/j.oraloncology.2014. 04.003 .

11. Schreiber RD, Old LJ, Smyth MJ. Cancer immunoediting: integrating immunity's roles in cancer suppression and promotion. Science (New York, NY). 2011;331(6024):1565-70. https://doi. org/10.1126/science.1203486.

12. Nguyen N, Bellile E, Thomas D, McHugh J, Rozek L, Virani S, et al. Tumor infiltrating lymphocytes and survival in patients with head and neck squamous cell carcinoma. Head Neck. 2016;38(7): 1074-84. https://doi.org/10.1002/hed.24406 A comprehensive comparison of immune cell infiltration between HNSCC subsites and HPV-status.

13. Costa NL, Goncalves AS, Martins AF, Arantes DA, Silva TA, Batista AC. Characterization of dendritic cells in lip and oral cavity squamous cell carcinoma. J Oral Pathol Med. 2016;45(6):41824. https://doi.org/10.1111/jop.12380.

14. Kindt N, Descamps G, Seminerio I, Bellier J, Lechien JR, Pottier $\mathrm{C}$, et al. Langerhans cell number is a strong and independent prognostic factor for head and neck squamous cell carcinomas. Oral Oncol. 2016;62:1-10. https://doi.org/10.1016/j. oraloncology.2016.08.016.

15. Partlova S, Boucek J, Kloudova K, Lukesova E, Zabrodsky M, Grega M, et al. Distinct patterns of intratumoral immune cell infiltrates in patients with HPV-associated compared to non-virally induced head and neck squamous cell carcinoma. Oncoimmunology. 2015;4(1):e965570. https://doi.org/10.4161/ 21624011.2014.965570.

16. Mandal R, Senbabaoglu Y, Desrichard A, Havel JJ, Dalin MG, Riaz N, et al. The head and neck cancer immune landscape and its immunotherapeutic implications. JCI Insight. 2016;1(17):e89829. https://doi.org/10.1172/jci.insight.89829.

17. Chen X, Yan B, Lou H, Shen Z, Tong F, Zhai A, et al. Immunological network analysis in HPV associated head and neck squamous cancer and implications for disease prognosis. Mol Immunol. 2018;96:28-36. https://doi.org/10.1016/j. molimm.2018.02.005 This study investigates the prognostic significance of various immune subsets for all HNSCC subsites as well as seperately for HPV-negative and -positive HNSCC.

18. Wang J, Sun H, Zeng Q, Guo XJ, Wang H, Liu HH, et al. HPVpositive status associated with inflamed immune microenvironment and improved response to anti-PD-1 therapy in head and neck squamous cell carcinoma. Sci Rep. 2019;9(1):13404. https://doi.org/10.1038/s41598-019-49771-0.

19. Masucci MT, Minopoli M, Carriero MV. Tumor associated neutrophils. Their role in tumorigenesis, metastasis, prognosis and therapy. Front Oncol. 2019;9:1146. https://doi.org/10.3389/fonc. 2019.01146

20. Zhang X, Zhang W, Yuan X, Fu M, Qian H, Xu W. Neutrophils in cancer development and progression: roles, mechanisms, and implications (review). Int J Oncol. 2016;49(3):857-67. https://doi. org/10.3892/ijo.2016.3616.

21. Trellakis S, Bruderek K, Dumitru CA, Gholaman H, Gu X, Bankfalvi A, et al. Polymorphonuclear granulocytes in human head and neck cancer: enhanced inflammatory activity, 
modulation by cancer cells and expansion in advanced disease. Int J Cancer. 2011;129(9):2183-93. https://doi.org/10.1002/ijc. 25892.

22. Dumitru CA, Bankfalvi A, Gu X, Eberhardt WE, Zeidler R, Lang $\mathrm{S}$, et al. Neutrophils activate tumoral CORTACTIN to enhance progression of orohypopharynx carcinoma. Front Immunol. 2013;4:33. https://doi.org/10.3389/fimmu.2013.00033.

23. Moy JD, Moskovitz JM, Ferris RL. Biological mechanisms of immune escape and implications for immunotherapy in head and neck squamous cell carcinoma. Eur J Cancer. 2017;76:152-66. https://doi.org/10.1016/j.ejca.2016.12.035.

24. Concha-Benavente F, Kansy B, Moskovitz J, Moy J, Chandran U, Ferris RL. PD-L1 mediates dysfunction in activated PD-1(+) NK cells in head and neck cancer patients. Cancer Immunol Res. 2018;6(12):1548-60. https://doi.org/10.1158/2326-6066.Cir-180062.

25. Wagner S, Wittekindt C, Reuschenbach M, Hennig B, Thevarajah $\mathrm{M}$, Wurdemann N, et al. CD56-positive lymphocyte infiltration in relation to human papillomavirus association and prognostic significance in oropharyngeal squamous cell carcinoma. Int J Cancer. 2016;138(9):2263-73. https://doi.org/10.1002/ijc.29962.

26. Gallo O, Libonati GA, Gallina E, Fini-Storchi O, Giannini A, Urso $\mathrm{C}$, et al. Langerhans cells related to prognosis in patients with laryngeal carcinoma. Arch Otolaryngol Head Neck Surg. 1991;117(9):1007-10. https://doi.org/10.1001/archotol.1991. 01870210079015.

27. Goldman SA, Baker E, Weyant RJ, Clarke MR, Myers JN, Lotze MT. Peritumoral CD1a-positive dendritic cells are associated with improved survival in patients with tongue carcinoma. Arch Otolaryngol Head Neck Surg. 1998;124(6):641-6. https://doi. org/10.1001/archotol.124.6.641.

28. Reichert TE, Scheuer C, Day R, Wagner W, Whiteside TL. The number of intratumoral dendritic cells and zeta-chain expression in $\mathrm{T}$ cells as prognostic and survival biomarkers in patients with oral carcinoma. Cancer. 2001;91(11):2136-47.

29. Yilmaz T, Gedikoglu G, Celik A, Onerci M, Turan E. Prognostic significance of Langerhans cell infiltration in cancer of the larynx. Otolaryngol Head Neck Surg. 2005;132(2):309-16. https://doi. org/10.1016/j.otohns.2004.04.018.

30. Bron L, Jandus C, Andrejevic-Blant S, Speiser DE, Monnier P, Romero P, et al. Prognostic value of arginase-II expression and regulatory T-cell infiltration in head and neck squamous cell carcinoma. Int J Cancer. 2013;132(3):E85-93. https://doi.org/10. 1002/ijc. 27728 .

31. Jardim JF, Gondak R, Galvis MM, Pinto CAL, Kowalski LP. A decreased peritumoral CD1a+ cell number predicts a worse prognosis in oral squamous cell carcinoma. Histopathology. 2018;72(6):905-13. https://doi.org/10.1111/his.13415.

32. Karpathiou G, Casteillo F, Giroult JB, Forest F, Fournel P, Monaya A, et al. Prognostic impact of immune microenvironment in laryngeal and pharyngeal squamous cell carcinoma: immune cell subtypes, immuno-suppressive pathways and clinicopathologic characteristics. Oncotarget. 2017;8(12):19310-22. https:// doi.org/10.18632/oncotarget.14242.

33. Chang CS, Chang JH, Hsu NC, Lin HY, Chung CY. Expression of CD80 and CD86 costimulatory molecules are potential markers for better survival in nasopharyngeal carcinoma. BMC Cancer. 2007;7:88. https://doi.org/10.1186/1471-2407-7-88.

34. O'Donnell RK, Mick R, Feldman M, Hino S, Wang Y, Brose MS, et al. Distribution of dendritic cell subtypes in primary oral squamous cell carcinoma is inconsistent with a functional response. Cancer Lett. 2007;255(1):145-52. https://doi.org/10.1016/j. canlet.2007.04.003.

35. Karakok M, Bayazit YA, Ucak R, Ozer E, Kanlikama M, Mumbuc S, et al. Langerhans cell related inflammatory reaction in laryngeal squamous cell carcinoma. Auris Nasus Larynx.
2003;30(1):81-4. https://doi.org/10.1016/s0385-8146(02)000251.

36. Gomes JO, de Vasconcelos CM, Fonseca FP, Gondak RO, Lopes MA, Vargas PA. CD1a+ and CD83+ Langerhans cells are reduced in lower lip squamous cell carcinoma. J Oral Pathol Med. 2016;45(6):433-9. https://doi.org/10.1111/jop.12389.

37. Hilly O, Strenov Y, Rath-Wolfson L, Hod R, Shkedy Y, Mizrachi $\mathrm{A}$, et al. The predictive value of dendritic cells in early squamous cell carcinoma of the tongue. Pathol Res Pract. 2016;212(12): 1138-43. https://doi.org/10.1016/j.prp.2016.09.011.

38. Matthews K, Leong CM, Baxter L, Inglis E, Yun K, Backstrom BT, et al. Depletion of Langerhans cells in human papillomavirus type 16-infected skin is associated with E6-mediated down regulation of E-cadherin. J Virol. 2003;77(15):8378-85. https://doi. org/10.1128/jvi.77.15.8378-8385.2003.

39. Guess JC, McCance DJ. Decreased migration of Langerhans precursor-like cells in response to human keratinocytes expressing human papillomavirus type $16 \mathrm{E} 6 / \mathrm{E} 7$ is related to reduced macrophage inflammatory protein-3alpha production. J Virol. 2005;79(23):14852-62. https://doi.org/10.1128/jvi.79.23.1485214862.2005

40. Pereira KM, Soares RC, Oliveira MC, Pinto LP, Costa AL. Immunohistochemical staining of Langerhans cells in HPVpositive and HPV-negative cases of oral squamous cells carcinoma. J Appl Oral Sci. 2011;19(4):378-83. https://doi.org/10.1590/ s1678-77572011005000013.

41. Hartmann E, Wollenberg B, Rothenfusser S, Wagner M, Wellisch $\mathrm{D}$, Mack B, et al. Identification and functional analysis of tumorinfiltrating plasmacytoid dendritic cells in head and neck cancer. Cancer Res. 2003;63(19):6478-87.

42. Han N, Zhang Z, Liu S, Ow A, Ruan M, Yang W, et al. Increased tumor-infiltrating plasmacytoid dendritic cells predicts poor prognosis in oral squamous cell carcinoma. Arch Oral Biol. 2017;78: 129-34. https://doi.org/10.1016/j.archoralbio.2017.02.012.

43. Pellicioli ACA, Bingle L, Farthing P, Lopes MA, Martins MD, Vargas PA. Immunosurveillance profile of oral squamous cell carcinoma and oral epithelial dysplasia through dendritic and Tcell analysis. J Oral Pathol Med. 2017;46(10):928-33. https://doi. org/10.1111/jop.12597.

44. Gilliet M, Cao W, Liu YJ. Plasmacytoid dendritic cells: sensing nucleic acids in viral infection and autoimmune diseases. Nat Rev Immunol. 2008;8(8):594-606. https://doi.org/10.1038/nri2358.

45. Lombardi VC, Khaiboullina SF, Rizvanov AA. Plasmacytoid dendritic cells, a role in neoplastic prevention and progression. Eur J Clin Investig. 2015;45(Suppl 1):1-8. https://doi.org/10. 1111/eci.12363.

46. Martinez FO, Gordon S. The M1 and M2 paradigm of macrophage activation: time for reassessment. F1000Prime Rep. 2014;6:13. https://doi.org/10.12703/p6-13.

47. Duray A, Demoulin S, Hubert P, Delvenne P, Saussez S. Immune suppression in head and neck cancers: a review. Clin Dev Immunol. 2010;2010:701657. https://doi.org/10.1155/2010/ 701657.

48. Mantovani A, Marchesi F, Malesci A, Laghi L, Allavena P. Tumour-associated macrophages as treatment targets in oncology. Nat Rev Clin Oncol. 2017;14(7):399-416. https://doi.org/10. 1038/nrclinonc.2016.217.

49. Marcus B, Arenberg D, Lee J, Kleer C, Chepeha DB, Schmalbach $\mathrm{CE}$, et al. Prognostic factors in oral cavity and oropharyngeal squamous cell carcinoma. Cancer. 2004;101(12):2779-87. https://doi.org/10.1002/cncr.20701.

50. Lu CF, Huang CS, Tjiu JW, Chiang CP. Infiltrating macrophage count: a significant predictor for the progression and prognosis of oral squamous cell carcinomas in Taiwan. Head Neck. 2010;32(1):18-25. https://doi.org/10.1002/hed.21138. 
51. Costa NL, Valadares MC, Souza PP, Mendonca EF, Oliveira JC, Silva TA, et al. Tumor-associated macrophages and the profile of inflammatory cytokines in oral squamous cell carcinoma. Oral Oncol. 2013;49(3):216-23. https://doi.org/10.1016/j. oraloncology.2012.09.012.

52. Seminerio I, Kindt N, Descamps G, Bellier J, Lechien JR, Mat Q, et al. High infiltration of CD68+ macrophages is associated with poor prognoses of head and neck squamous cell carcinoma patients and is influenced by human papillomavirus. Oncotarget. 2018;9(13):11046-59. https://doi.org/10.18632/oncotarget. 24306.

53. Yu GT, Bu LL, Huang CF, Zhang WF, Chen WJ, Gutkind JS, et al. PD-1 blockade attenuates immunosuppressive myeloid cells due to inhibition of CD47/SIRPalpha axis in HPV negative head and neck squamous cell carcinoma. Oncotarget. 2015;6(39): 42067-80. https://doi.org/10.18632/oncotarget.5955.

54. Ni YH, Ding L, Huang XF, Dong YC, Hu QG, Hou YY. Microlocalization of CD68+ tumor-associated macrophages in tumor stroma correlated with poor clinical outcomes in oral squamous cell carcinoma patients. Tumour Biol. 2015;36(7):5291-8. https://doi.org/10.1007/s13277-015-3189-5.

55. Liu SY, Chang LC, Pan LF, Hung YJ, Lee CH, Shieh YS. Clinicopathologic significance of tumor cell-lined vessel and microenvironment in oral squamous cell carcinoma. Oral Oncol. 2008;44(3):277-85. https://doi.org/10.1016/j.oraloncology.2007. 02.007 .

56. Wolf GT, Chepeha DB, Bellile E, Nguyen A, Thomas D, McHugh J. Tumor infiltrating lymphocytes (TIL) and prognosis in oral cavity squamous carcinoma: a preliminary study. Oral Oncol. 2015;51(1):90-5. https://doi.org/10.1016/j.oraloncology. 2014.09.006.

57. Lee YS, Park JY, Cho KJ, Kim SB, Lee SW, Choi SH, et al. Composition of inflammatory cells regulating the response to concurrent chemoradiation therapy for HPV $(+)$ tonsil cancer. Oral Oncol. 2015;51(12):1113-9. https://doi.org/10.1016/j. oraloncology.2015.10.001.

58. $\mathrm{Hu}$ Y, He MY, Zhu LF, Yang CC, Zhou ML, Wang Q, et al. Tumor-associated macrophages correlate with the clinicopathological features and poor outcomes via inducing epithelial to mesenchymal transition in oral squamous cell carcinoma. J Exp Clin Cancer Res. 2016;35:12. https://doi.org/10.1186/s13046-0150281-z.

59. Wansom D, Light E, Thomas D, Worden F, Prince M, Urba S, et al. Infiltrating lymphocytes and human papillomavirus-16associated oropharyngeal cancer. Laryngoscope. 2012;122(1): 121-7. https://doi.org/10.1002/lary.22133.

60. Oguejiofor K, Galletta-Williams H, Dovedi SJ, Roberts DL, Stern PL, West CM. Distinct patterns of infiltrating CD8+ T cells in $\mathrm{HPV}+$ and CD68 macrophages in HPV- oropharyngeal squamous cell carcinomas are associated with better clinical outcome but PD-L1 expression is not prognostic. Oncotarget. 2017;8(9): 14416-27. https://doi.org/10.18632/oncotarget.14796.

61. He KF, Zhang L, Huang CF, Ma SR, Wang YF, Wang WM, et al. CD163+ tumor-associated macrophages correlated with poor prognosis and cancer stem cells in oral squamous cell carcinoma. Biomed Res Int. 2014;2014:838632. https://doi.org/10.1155/ 2014/838632.

62. Fujii N, Shomori K, Shiomi T, Nakabayashi M, Takeda C, Ryoke $\mathrm{K}$, et al. Cancer-associated fibroblasts and CD163-positive macrophages in oral squamous cell carcinoma: their clinicopathological and prognostic significance. J Oral Pathol Med. 2012;41(6): 444-51. https://doi.org/10.1111/j.1600-0714.2012.01127.x.

63. Verreck FA, de Boer T, Langenberg DM, van der Zanden L, Ottenhoff TH. Phenotypic and functional profiling of human proinflammatory type- 1 and anti-inflammatory type- 2 macrophages in response to microbial antigens and IFN-gamma- and CD40L- mediated costimulation. J Leukoc Biol. 2006;79(2):285-93. https://doi.org/10.1189/jlb.0105015.

64. Chiu KC, Lee CH, Liu SY, Chou YT, Huang RY, Huang SM, et al. Polarization of tumor-associated macrophages and Gas6/Axl signaling in oral squamous cell carcinoma. Oral Oncol. 2015;51(7):683-9. https://doi.org/10.1016/j.oraloncology.2015. 04.004 .

65. Chang KP, Kao HK, Yen TC, Chang YL, Liang Y, Liu SC, et al. Overexpression of macrophage inflammatory protein-3alpha in oral cavity squamous cell carcinoma is associated with nodal metastasis. Oral Oncol. 2011;47(2):108-13. https://doi.org/10.1016/ j.oraloncology.2010.11.012.

66. Pirila E, Vayrynen O, Sundquist E, Pakkila K, Nyberg P, Nurmenniemi S, et al. Macrophages modulate migration and invasion of human tongue squamous cell carcinoma. PLoS One. 2015;10(3):e0120895. https://doi.org/10.1371/journal.pone. 0120895.

67. Matsuoka Y, Yoshida R, Nakayama H, Nagata M, Hirosue A, Tanaka T, et al. The tumour stromal features are associated with resistance to 5-FU-based chemoradiotherapy and a poor prognosis in patients with oral squamous cell carcinoma. Apmis. 2015;123(3):205-14. https://doi.org/10.1111/apm.12344.

68. Wang S, Sun M, Gu C, Wang X, Chen D, Zhao E, et al. Expression of CD163, interleukin-10, and interferon-gamma in oral squamous cell carcinoma: mutual relationships and prognostic implications. Eur J Oral Sci. 2014;122(3):202-9. https://doi. org/10.1111/eos.12131.

69. Balermpas P, Rodel F, Liberz R, Oppermann J, Wagenblast J, Ghanaati S, et al. Head and neck cancer relapse after chemoradiotherapy correlates with $\mathrm{CD} 163+$ macrophages in primary tumour and $\mathrm{CD} 11 \mathrm{~b}+$ myeloid cells in recurrences. Br J Cancer. 2014;111(8):1509-18. https://doi.org/10.1038/bjc.2014.446.

70. Schneider K, Marbaix E, Bouzin C, Hamoir M, Mahy P, Bol V, et al. Immune cell infiltration in head and neck squamous cell carcinoma and patient outcome: a retrospective study. Acta Oncol. 2018;57(9):1165-72. https://doi.org/10.1080/0284186X. 2018.1445287.

71. Ou D, Adam J, Garberis I, Blanchard P, Nguyen F, Levy A, et al. Influence of tumor-associated macrophages and HLA class I expression according to HPV status in head and neck cancer patients receiving chemo/bioradiotherapy. Radiother Oncol. 2019;130:89 96. https://doi.org/10.1016/j.radonc.2018.08.013.

72. Gameiro SF, Ghasemi F, Barrett JW, Koropatnick J, Nichols AC, Mymryk JS, et al. Treatment-naive HPV+ head and neck cancers display a T-cell-inflamed phenotype distinct from their HPVcounterparts that has implications for immunotherapy. Oncoimmunology. 2018;7(10):e1498439. https://doi.org/10. 1080/2162402X.2018.1498439.

73. Saloura V, Izumchenko E, Zuo Z, Bao R, Korzinkin M, Ozerov I, et al. Immune profiles in primary squamous cell carcinoma of the head and neck. Oral Oncol. 2019;96:77-88. https://doi.org/10. 1016/j.oraloncology.2019.06.032.

74. Russell S, Angell T, Lechner M, Liebertz D, Correa A, Sinha U, et al. Immune cell infiltration patterns and survival in head and neck squamous cell carcinoma. Head Neck Oncol. 2013;5(3):24.

75. Ostrand-Rosenberg S, Sinha P. Myeloid-derived suppressor cells: linking inflammation and cancer. J Immunol. 2009;182(8):4499506. https://doi.org/10.4049/jimmunol.0802740.

76. Almand B, Clark JI, Nikitina E, van Beynen J, English NR, Knight SC, et al. Increased production of immature myeloid cells in cancer patients: a mechanism of immunosuppression in cancer. J Immunol. 2001;166(1):678-89. https://doi.org/10.4049/ jimmunol.166.1.678.

77. Sinha P, Clements VK, Bunt SK, Albelda SM, OstrandRosenberg S. Cross-talk between myeloid-derived suppressor cells and macrophages subverts tumor immunity toward a type 
2 response. J Immunol. 2007;179(2):977-83. https://doi.org/10. 4049/jimmunol.179.2.977.

78. Bu LL, Yu GT, Deng WW, Mao L, Liu JF, Ma SR, et al. Targeting STAT3 signaling reduces immunosuppressive myeloid cells in head and neck squamous cell carcinoma. Oncoimmunology. 2016;5(5):e1130206. https://doi.org/10.1080/ $2162402 x .2015 .1130206$.

79. Ma X, Sheng S, Wu J, Jiang Y, Gao X, Cen X, et al. LncRNAs as an intermediate in HPV16 promoting myeloid-derived suppressor cell recruitment of head and neck squamous cell carcinoma. Oncotarget. 2017;8(26):42061-75. https://doi.org/10.18632/ oncotarget.14939.

80. Zhang N, Bevan MJ. CD8(+) T cells: foot soldiers of the immune system. Immunity. 2011;35(2):161-8. https://doi.org/10.1016/j. immuni.2011.07.010.

81. Balermpas P, Michel Y, Wagenblast J, Seitz O, Weiss C, Rodel F, et al. Tumour-infiltrating lymphocytes predict response to definitive chemoradiotherapy in head and neck cancer. Br J Cancer. 2014;110(2):501-9. https://doi.org/10.1038/bjc.2013.640.

82. Balermpas P, Rodel F, Rodel C, Krause M, Linge A, Lohaus F, et al. CD8+ tumour-infiltrating lymphocytes in relation to HPV status and clinical outcome in patients with head and neck cancer after postoperative chemoradiotherapy: a multicentre study of the German cancer consortium radiation oncology group (DKTKROG). Int J Cancer. 2016;138(1):171-81. https://doi.org/10. 1002/ijc. 29683.

83. Kim HR, Ha SJ, Hong MH, Heo SJ, Koh YW, Choi EC, et al. PDL1 expression on immune cells, but not on tumor cells, is a favorable prognostic factor for head and neck cancer patients. Sci Rep. 2016;6:36956. https://doi.org/10.1038/srep36956.

84. de Ruiter EJ, Ooft ML, Devriese LA, Willems SM. The prognostic role of tumor infiltrating T-lymphocytes in squamous cell carcinoma of the head and neck: a systematic review and meta-analysis. Oncoimmunology. 2017;6(11):e1356148. https://doi.org/10. 1080/2162402X.2017.1356148.

85. Spector ME, Bellile E, Amlani L, Zarins K, Smith J, Brenner JC, et al. Prognostic value of tumor-infiltrating lymphocytes in head and neck squamous cell carcinoma. JAMA Otolaryngol Head Neck Surg. 2019. https://doi.org/10.1001/jamaoto.2019.2427.

86. Fang J, Li X, Ma D, Liu X, Chen Y, Wang Y, et al. Prognostic significance of tumor infiltrating immune cells in oral squamous cell carcinoma. BMC Cancer. 2017;17(1):375. https://doi.org/10. 1186/s12885-017-3317-2.

87. Zhou C, Wu Y, Jiang L, Li Z, Diao P, Wang D, et al. Density and location of $\mathrm{CD} 3(+)$ and $\mathrm{CD} 8(+)$ tumor-infiltrating lymphocytes correlate with prognosis of oral squamous cell carcinoma. J Oral Pathol Med. 2018;47(4):359-67. https://doi.org/10.1111/jop. 12698.

88. Stasikowska-Kanicka O, Wagrowska-Danilewicz M, Danilewicz M. Immunohistochemical analysis of Foxp3(+), CD4(+), CD8(+) cell infiltrates and PD-L1 in oral squamous cell carcinoma. Pathol Oncol Res. 2018;24(3):497-505. https://doi.org/10.1007/s12253017-0270-y.

89. Watanabe Y, Katou F, Ohtani H, Nakayama T, Yoshie O, Hashimoto K. Tumor-infiltrating lymphocytes, particularly the balance between CD8(+) T cells and CCR4(+) regulatory T cells, affect the survival of patients with oral squamous cell carcinoma. Oral Surg Oral Med Oral Pathol Oral Radiol Endod. 2010;109(5): 744-52. https://doi.org/10.1016/j.tripleo.2009.12.015.

90. Feng Z, Bethmann D, Kappler M, Ballesteros-Merino C, Eckert A, Bell RB, et al. Multiparametric immune profiling in HPV- oral squamous cell cancer. JCI Insight. 2017;2(14). https://doi.org/10. 1172/jci.insight.93652 This study, performing multiplex IHC in a large cohort of HPV-unrelated OCSCC, showed that the spatial distance between CD8+ TIL and Treg at the tumor invasive margin was of importance for prognosis.
91. Wirsing AM, Ervik IK, Seppola M, Uhlin-Hansen L, Steigen SE, Hadler-Olsen E. Presence of high-endothelial venules correlates with a favorable immune microenvironment in oral squamous cell carcinoma. Mod Pathol. 2018;31(6):910-22. https://doi.org/10. 1038/s41379-018-0019-5.

92. Ahn H, Yang JM, Kim H, Chung JH, Ahn SH, Jeong WJ, et al. Clinicopathologic implications of the miR-197/PD-L1 axis in oral squamous cell carcinoma. Oncotarget. 2017;8(39):66178-94. https://doi.org/10.18632/oncotarget.19842.

93. Kogashiwa Y, Yasuda M, Sakurai H, Nakahira M, Sano Y, Gonda $\mathrm{K}$, et al. PD-L1 expression confers better prognosis in locally advanced oral squamous cell carcinoma. Anticancer Res. 2017;37(3):1417-24. https://doi.org/10.21873/anticanres.11465.

94. Mattox AK, Lee J, Westra WH, Pierce RH, Ghossein R, Faquin $\mathrm{WC}$, et al. PD-1 expression in head and neck squamous cell carcinomas derives primarily from functionally anergic CD4(+) TILs in the presence of PD-L1(+) TAMs. Cancer Res. 2017;77(22): 6365-74. https://doi.org/10.1158/0008-5472.Can-16-3453.

95. Wu L, Deng WW, Huang CF, Bu LL, Yu GT, Mao L, et al. Expression of VISTA correlated with immunosuppression and synergized with CD8 to predict survival in human oral squamous cell carcinoma. Cancer Immunol Immunother. 2017;66(5):62736. https://doi.org/10.1007/s00262-017-1968-0.

96. Dayan D, Salo T, Salo S, Nyberg P, Nurmenniemi S, Costea DE, et al. Molecular crosstalk between cancer cells and tumor microenvironment components suggests potential targets for new therapeutic approaches in mobile tongue cancer. Cancer Med. 2012;1(2):128-40. https://doi.org/10.1002/cam4.24.

97. Boxberg M, Leising L, Steiger K, Jesinghaus M, Alkhamas A, Mielke M, et al. Composition and clinical impact of the immunologic tumor microenvironment in oral squamous cell carcinoma. J Immunol. 2019;202(1):278-91. https://doi.org/10.4049/ jimmunol.1800242.

98. Chen YP, Wang YQ, Lv JW, Li YQ, Chua MLK, Le QT, et al. Identification and validation of novel microenvironment-based immune molecular subgroups of head and neck squamous cell carcinoma: implications for immunotherapy. Ann Oncol. 2019;30(1):68-75. https://doi.org/10.1093/annonc/mdy470.

99. Ni YH, Zhang XX, Lu ZY, Huang XF, Wang ZY, Yang Y, et al. Tumor-infiltrating CD1a(+) DCs and CD8(+)/FoxP3(+) ratios served as predictors for clinical outcomes in tongue squamous cell carcinoma patients. Pathol Oncol Res. 2019. https://doi.org/10. 1007/s12253-019-00701-5.

100. Huang Z, Xie N, Liu H, Wan Y, Zhu Y, Zhang M, et al. The prognostic role of tumour-infiltrating lymphocytes in oral squamous cell carcinoma: a meta-analysis. J Oral Pathol Med. 2019;48(9):788-98. https://doi.org/10.1111/jop.12927.

101. Hadler-Olsen E, Wirsing AM. Tissue-infiltrating immune cells as prognostic markers in oral squamous cell carcinoma: a systematic review and meta-analysis. Br J Cancer. 2019;120(7):714-27. https://doi.org/10.1038/s41416-019-0409-6.

102. Nordfors C, Grun N, Tertipis N, Ahrlund-Richter A, Haeggblom $\mathrm{L}$, Sivars L, et al. CD8+ and CD4+ tumour infiltrating lymphocytes in relation to human papillomavirus status and clinical outcome in tonsillar and base of tongue squamous cell carcinoma. Eur J Cancer. 2013;49(11):2522-30. https://doi.org/10.1016/j.ejca. 2013.03.019.

103. Nasman A, Romanitan M, Nordfors C, Grun N, Johansson H, Hammarstedt L, et al. Tumor infiltrating CD8+ and Foxp3+ lymphocytes correlate to clinical outcome and human papillomavirus (HPV) status in tonsillar cancer. PLoS One. 2012;7(6):e38711. https://doi.org/10.1371/journal.pone.0038711.

104. Jung AC, Guihard S, Krugell S, Ledrappier S, Brochot A, Dalstein $\mathrm{V}$, et al. CD8-alpha T-cell infiltration in human papillomavirusrelated oropharyngeal carcinoma correlates with improved patient 
prognosis. Int J Cancer. 2013;132(2):E26-36. https://doi.org/10. 1002/ijc. 27776

105. Poropatich K, Hernandez D, Fontanarosa J, Brown K, Woloschak G, Paintal A, et al. Peritumoral cuffing by T-cell tumor-infiltrating lymphocytes distinguishes HPV-related oropharyngeal squamous cell carcinoma from oral cavity squamous cell carcinoma. J Oral Pathol Med. 2017;46(10):972-8. https://doi.org/10.1111/jop. 12605.

106. Oguejiofor K, Hall J, Slater C, Betts G, Hall G, Slevin N, et al. Stromal infiltration of CD8 T cells is associated with improved clinical outcome in HPV-positive oropharyngeal squamous carcinoma. Br J Cancer. 2015;113(6):886-93. https://doi.org/10.1038/ bjc.2015.277.

107. De Meulenaere A, Vermassen T, Aspeslagh S, Deron P, Duprez F, Laukens D, et al. Tumor PD-L1 status and CD8(+) tumorinfiltrating T cells: markers of improved prognosis in oropharyngeal cancer. Oncotarget. 2017;8(46):80443-52. https://doi.org/10. 18632/oncotarget.19045.

108. Solomon B, Young RJ, Bressel M, Urban D, Hendry S, Thai A, et al. Prognostic significance of PD-L1(+) and CD8(+) immune cells in $\mathrm{HPV}(+)$ Oropharyngeal squamous cell carcinoma. Cancer Immunol Res. 2018;6(3):295-304. https://doi.org/10.1158/23266066.Cir-17-0299.

109. Ward MJ, Thirdborough SM, Mellows T, Riley C, Harris S, Suchak K, et al. Tumour-infiltrating lymphocytes predict for outcome in HPV-positive oropharyngeal cancer. Br J Cancer. 2014;110(2):489-500. https://doi.org/10.1038/bjc.2013.639.

110. Badoual C, Hans S, Merillon N, Van Ryswick C, Ravel P, Benhamouda N, et al. PD-1-expressing tumor-infiltrating T cells are a favorable prognostic biomarker in HPV-associated head and neck cancer. Cancer Res. 2013;73(1):128-38. https://doi.org/10. 1158/0008-5472.CAN-12-2606.

111. Hoesli R, Birkeland AC, Rosko AJ, Issa M, Chow KL, Michmerhuizen NL, et al. Proportion of CD4 and CD8 tumor infiltrating lymphocytes predicts survival in persistent/recurrent laryngeal squamous cell carcinoma. Oral Oncol. 2018;77:83-9. https://doi.org/10.1016/j.oraloncology.2017.12.003.

112. Chatzopoulos K, Kotoula V, Manoussou K, Markou K, Vlachtsis $\mathrm{K}$, Angouridakis N, et al. Tumor infiltrating lymphocytes and $\mathrm{CD} 8+\mathrm{T}$ cell subsets as prognostic markers in patients with surgically treated laryngeal squamous cell carcinoma. Head Neck Pathol. 2019. https://doi.org/10.1007/s12105-019-01101-6.

113. Kim HJ, Cantor H. CD4 T-cell subsets and tumor immunity: the helpful and the not-so-helpful. Cancer Immunol Res. 2014;2(2): 91-8. https://doi.org/10.1158/2326-6066.CIR-13-0216.

114. Loose D, Signore A, Bonanno E, Vermeersch H, Dierckx R, Deron P, et al. Prognostic value of CD25 expression on lymphocytes and tumor cells in squamous-cell carcinoma of the head and neck. Cancer Biother Radiopharm. 2008;23(1):25-33. https://doi. org/10.1089/cbr.2007.0373.

115. Moreira G, Fulgencio LB, De Mendonça EF, Leles CR, Batista AC, da Silva TA. T regulatory cell markers in oral squamous cell carcinoma: relationship with survival and tumor aggressiveness. Oncol Lett. 2010;1(1):127-32. https://doi.org/10.3892/ol_ 00000023.

116. Cillo AR, Kurten CHL, Tabib T, Qi Z, Onkar S, Wang T, et al. Immune landscape of viral- and carcinogen-driven head and neck Cancer. Immunity. 2019. https://doi.org/10.1016/j.immuni.2019. 11.014 In this recent work scRNAseq was used to identify tumor-infiltrating immune cell subsets more pronounced in HPV-related HNSCC than HPV-unrelated HNSCC.

117. Sakaguchi S, Miyara M, Costantino CM, Hafler DA. FOXP3+ regulatory $\mathrm{T}$ cells in the human immune system. Nat Rev Immunol. 2010;10(7):490-500. https://doi.org/10.1038/nri2785.

118. Shang B, Liu Y, Jiang SJ, Liu Y. Prognostic value of tumorinfiltrating FoxP3+ regulatory $\mathrm{T}$ cells in cancers: a systematic review and meta-analysis. Sci Rep. 2015;5:15179. https://doi. org/10.1038/srep15179.

119. Badoual C, Hans S, Rodriguez J, Peyrard S, Klein C, Agueznay $\mathrm{Nel} \mathrm{H}$, et al. Prognostic value of tumor-infiltrating CD4+ T-cell subpopulations in head and neck cancers. Clin Cancer Res. 2006;12(2):465-72. https://doi.org/10.1158/1078-0432.CCR-051886.

120. Seminerio I, Descamps G, Dupont S, de Marrez L, Laigle JA, Lechien JR, et al. Infiltration of FoxP3+ regulatory T cells is a strong and independent prognostic factor in head and neck squamous cell carcinoma. Cancers (Basel). 2019;11(2). https://doi.org/ 10.3390/cancers11020227.

121. Liang YJ, Liu HC, Su YX, Zhang TH, Chu M, Liang LZ, et al. Foxp3 expressed by tongue squamous cell carcinoma cells correlates with clinicopathologic features and overall survival in tongue squamous cell carcinoma patients. Oral Oncol. 2011;47(7):56670. https://doi.org/10.1016/j.oraloncology.2011.04.017.

122. Zhou X, Su YX, Lao XM, Liang YJ, Liao GQ. CD19(+)IL-10(+) regulatory $\mathrm{B}$ cells affect survival of tongue squamous cell carcinoma patients and induce resting CD4(+) $\mathrm{T}$ cells to CD4(+ )Foxp3(+) regulatory $\mathrm{T}$ cells. Oral Oncol. 2016;53:27-35. https://doi.org/10.1016/j.oraloncology.2015.11.003.

123. Song JJ, Zhao SJ, Fang J, Ma D, Liu XQ, Chen XB, et al. Foxp3 overexpression in tumor cells predicts poor survival in oral squamous cell carcinoma. BMC Cancer. 2016;16:530. https://doi.org/ 10.1186/s12885-016-2419-6.

124. Chen WY, Wu CT, Wang CW, Lan KH, Liang HK, Huang BS, et al. Prognostic significance of tumor-infiltrating lymphocytes in patients with operable tongue cancer. Radiat Oncol. 2018;13(1): 157. https://doi.org/10.1186/s13014-018-1099-6.

125. Fujita Y, Okamoto M, Goda H, Tano T, Nakashiro K, Sugita A, et al. Prognostic significance of interleukin-8 and CD163-positive cell-infiltration in tumor tissues in patients with oral squamous cell carcinoma. PLoS One. 2014;9(12):e110378. https://doi.org/10. 1371/journal.pone.0110378.

126. Echarti A, Hecht M, Buttner-Herold M, Haderlein M, Hartmann A, Fietkau R, et al. CD8+ and regulatory T cells differentiate tumor immune phenotypes and predict survival in locally advanced head and neck cancer. Cancers (Basel). 2019;11(9). https://doi.org/10.3390/cancers11091398.

127. Magg T, Mannert J, Ellwart JW, Schmid I, Albert MH Subcellular localization of FOXP3 in human regulatory and nonregulatory T cells. Eur J Immunol. 2012;42(6):1627-38. https://doi.org/10.1002/eji.201141838.

128. Chen C, Rowell EA, Thomas RM, Hancock WW, Wells AD. Transcriptional regulation by Foxp3 is associated with direct promoter occupancy and modulation of histone acetylation. J Biol Chem. 2006;281(48):36828-34. https://doi.org/10.1074/jbc. M608848200.

129. Weed DT, Walker G, De La Fuente AC, Nazarian R, Vella JL, Gomez-Fernandez CR, et al. FOXP3 subcellular localization predicts recurrence in oral squamous cell carcinoma. PLoS One. 2013;8(8):e71908. https://doi.org/10.1371/journal.pone.0071908.

130. Kindt N, Descamps G, Seminerio I, Bellier J, Lechien JR, Mat Q, et al. High stromal Foxp3-positive T cell number combined to tumor stage improved prognosis in head and neck squamous cell carcinoma. Oral Oncol. 2017;67:183-91. https://doi.org/10.1016/ j.oraloncology.2017.02.023.

131. Park K, Cho KJ, Lee M, Yoon DH, Kim SB. Importance of FOXP3 in prognosis and its relationship with p16 in tonsillar squamous cell carcinoma. Anticancer Res. 2013;33(12):5667-73.

132. Weller MA, Ward MC, Berriochoa C, Reddy CA, Trosman S, Greskovich JF, et al. Predictors of distant metastasis in human papillomavirus-associated oropharyngeal cancer. Head Neck. 2017;39(5):940-6. https://doi.org/10.1002/hed.24711. 
133. Punt S, Dronkers EA, Welters MJ, Goedemans R, Koljenovic S, Bloemena $\mathrm{E}$, et al. A beneficial tumor microenvironment in oropharyngeal squamous cell carcinoma is characterized by a high $\mathrm{T}$ cell and low IL-17(+) cell frequency. Cancer Immunol Immunother. 2016;65(4):393-403. https://doi.org/10.1007/ s00262-016-1805-x.

134. Krupar R, Robold K, Gaag D, Spanier G, Kreutz M, Renner K, et al. Immunologic and metabolic characteristics of HPV-negative and HPV-positive head and neck squamous cell carcinomas are strikingly different. Virchows Arch. 2014;465(3):299-312. https://doi.org/10.1007/s00428-014-1630-6.

135. Lechner A, Schlosser H, Rothschild SI, Thelen M, Reuter S, Zentis P, et al. Characterization of tumor-associated T-lymphocyte subsets and immune checkpoint molecules in head and neck squamous cell carcinoma. Oncotarget. 2017;8(27):44418-33. https:// doi.org/10.18632/oncotarget.17901.

136. Flynn NJ, Somasundaram R, Arnold KM, Sims-Mourtada J. The multifaceted roles of B cells in solid tumors: emerging treatment opportunities. Target Oncol. 2017;12(2):139-52. https://doi.org/ 10.1007/s11523-017-0481-x.

137. Deola S, Panelli MC, Maric D, Selleri S, Dmitrieva NI, Voss CY, et al. Helper B cells promote cytotoxic T cell survival and proliferation independently of antigen presentation through CD27/CD70 interactions. J Immunol. 2008;180(3):1362-72. https://doi.org/10.4049/jimmunol.180.3.1362.

138. Schwartz M, Zhang Y, Rosenblatt JD. B cell regulation of the antitumor response and role in carcinogenesis. J Immunother Cancer. 2016;4:40. https://doi.org/10.1186/s40425-016-0145-x.

139. Lechner A, Schlosser HA, Thelen M, Wennhold K, Rothschild SI, Gilles R, et al. Tumor-associated B cells and humoral immune response in head and neck squamous cell carcinoma. Oncoimmunology. 2019;8(3):1535293. https://doi.org/10.1080/ 2162402X.2018.1535293 First study reporting on extensive flow cytometric phenotyping of tumor-infiltrating B cells using a small set of HNSCC subsites.

140. Wood O, Clarke J, Woo J, Mirza AH, Woelk CH, Thomas GJ, et al. Head and neck squamous cell carcinomas are characterized by a stable immune signature within the primary tumor over time and space. Clin Cancer Res. 2017;23(24):7641-9. https://doi.org/ 10.1158/1078-0432.CCR-17-0373.

141. Hladikova K, Koucky V, Boucek J, Laco J, Grega M, Hodek M, et al. Tumor-infiltrating B cells affect the progression of oropharyngeal squamous cell carcinoma via cell-to-cell interactions with CD8(+) T cells. J Immunother Cancer. 2019;7(1):261. https://doi. org/10.1186/s40425-019-0726-6.

142. Pretscher D, Distel LV, Grabenbauer GG, Wittlinger M, Buettner $\mathrm{M}$, Niedobitek G. Distribution of immune cells in head and neck cancer: CD8+ T-cells and CD20+ B-cells in metastatic lymph nodes are associated with favourable outcome in patients with oro- and hypopharyngeal carcinoma. BMC Cancer. 2009;9:292. https://doi.org/10.1186/1471-2407-9-292.

143. Taghavi N, Mohsenifar Z, Baghban AA, Arjomandkhah A. CD20+ tumor infiltrating B lymphocyte in oral squamous cell carcinoma: correlation with clinicopathologic characteristics and heat shock protein 70 expression. Pathol Res Int. 2018;2018: 4810751. https://doi.org/10.1155/2018/4810751.

144. Rosser EC, Mauri C. Regulatory B cells: origin, phenotype, and function. Immunity. 2015;42(4):607-12. https://doi.org/10.1016/ j.immuni.2015.04.005.

145. Distel LV, Fickenscher R, Dietel K, Hung A, Iro H, Zenk J, et al. Tumour infiltrating lymphocytes in squamous cell carcinoma of the oro- and hypopharynx: prognostic impact may depend on type of treatment and stage of disease. Oral Oncol. 2009;45(10):e16774. https://doi.org/10.1016/j.oraloncology.2009.05.640.
146. Drayton DL, Liao S, Mounzer RH, Ruddle NH. Lymphoid organ development: from ontogeny to neogenesis. Nat Immunol. 2006;7(4):344-53. https://doi.org/10.1038/ni1330.

147. Wirsing AM, Rikardsen OG, Steigen SE, Uhlin-Hansen L, Hadler-Olsen E. Characterisation and prognostic value of tertiary lymphoid structures in oral squamous cell carcinoma. BMC Clin Pathol. 2014;14:38. https://doi.org/10.1186/1472-6890-14-38.

148. Shiga K, Hara M, Nagasaki T, Sato T, Takahashi H, Takeyama H. Cancer-associated fibroblasts: their characteristics and their roles in tumor growth. Cancers (Basel). 2015;7(4):2443-58. https://doi. org/10.3390/cancers7040902.

149. Harper J, Sainson RC. Regulation of the anti-tumour immune response by cancer-associated fibroblasts. Semin Cancer Biol. 2014;25:69-77. https://doi.org/10.1016/j.semcancer.2013.12.005.

150. Li H, Zhang J, Chen SW, Liu LL, Li L, Gao F, et al. Cancerassociated fibroblasts provide a suitable microenvironment for tumor development and progression in oral tongue squamous cancer. J Transl Med. 2015;13:198. https://doi.org/10.1186/s12967015-0551-8.

151. Lim KP, Cirillo N, Hassona Y, Wei W, Thurlow JK, Cheong SC, et al. Fibroblast gene expression profile reflects the stage of tumour progression in oral squamous cell carcinoma. J Pathol. 2011;223(4):459-69. https://doi.org/10.1002/path.2841.

152. Choi SY, Oh SY, Kang SH, Kang SM, Kim J, Lee HJ, et al. NAB 2-expressing cancer-associated fibroblast promotes hnscc progression. Cancers (Basel). 2019;11(3). https://doi.org/10.3390/ cancers11030388.

153. Yu B, Wu K, Wang X, Zhang J, Wang L, Jiang Y, et al. Periostin secreted by cancer-associated fibroblasts promotes cancer stemness in head and neck cancer by activating protein tyrosine kinase 7. Cell Death Dis. 2018;9(11):1082. https://doi.org/10. 1038/s41419-018-1116-6.

154. Dhanda J, Triantafyllou A, Liloglou T, Kalirai H, Lloyd B, Hanlon $\mathrm{R}$, et al. SERPINE1 and SMA expression at the invasive front predict extracapsular spread and survival in oral squamous cell carcinoma. Br J Cancer. 2014;111(11):2114-21. https://doi.org/ 10.1038/bjc. 2014.500

155. Lai SL, Tan ML, Hollows RJ, Robinson M, Ibrahim M, Margielewska S, et al. Collagen induces a more proliferative, migratory and chemoresistant phenotype in head and neck cancer via DDR1. Cancers (Basel). 2019;11(11). https://doi.org/10.3390/ cancers11111766.

156. Puram SV, Tirosh I, Parikh AS, Patel AP, Yizhak K, Gillespie S, et al. Single-cell transcriptomic analysis of primary and metastatic tumor ecosystems in head and neck cancer. Cell. 2017;171(7): 1611-24.e24. https://doi.org/10.1016/j.cell.2017.10.044 Seminal paper using single cell transcriptomic analysis in HNSCC, finding a profound role for CAFs in promoting an EMT profile in tumor cells.

157. Cancer Genome Atlas N. Comprehensive genomic characterization of head and neck squamous cell carcinomas. Nature. 2015;517(7536):576-82. https://doi.org/10.1038/nature14129.

158. Binnewies M, Roberts EW, Kersten K, Chan V, Fearon DF, Merad M, et al. Understanding the tumor immune microenvironment (TIME) for effective therapy. Nat Med. 2018;24(5):541-50. https://doi.org/10.1038/s41591-018-0014-x.

159. Lyu H, Li M, Jiang Z, Liu Z, Wang X. Correlate the TP53 mutation and the HRAS mutation with immune signatures in head and neck squamous cell cancer. Comput Struct Biotechnol J. 2019;17: 1020-30. https://doi.org/10.1016/j.csbj.2019.07.009.

Publisher's Note Springer Nature remains neutral with regard to jurisdictional claims in published maps and institutional affiliations. 